
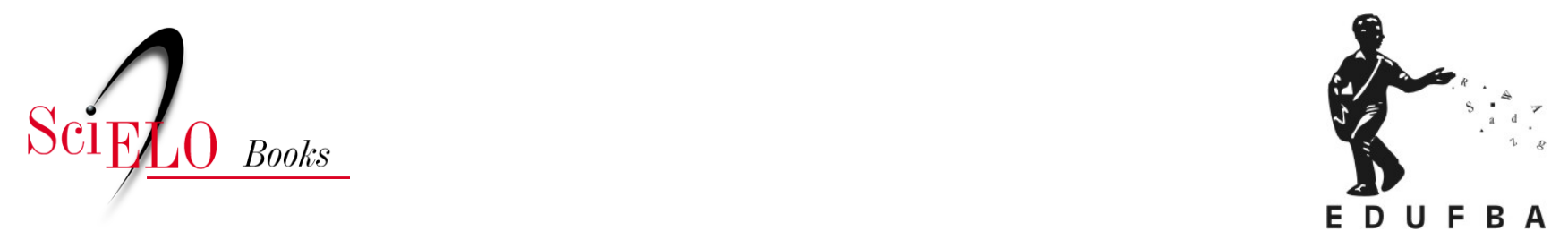

\title{
Prefácio \\ Paulo Freire, Vygotsky, Freinet, Dewey e Anísio Teixeira usariam o WhatsApp!
}

\author{
Marco Silva
}

SILVA, M. Prefácio - Paulo Freire, Vygotsky, Freinet, Dewey e Anísio Teixeira usariam o WhatsApp! In: PORTO, C., OLIVEIRA, K.E., and CHAGAS, A., comp. Whatsapp e educação: entre mensagens, imagens e sons [online]. Salvador: Ilhéus: EDUFBA; EDITUS, 2017, pp. 15-26. ISBN 978-85-232-2020-4. https://doi.org/10.7476/9788523220204.0002.

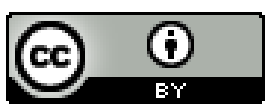

All the contents of this work, except where otherwise noted, is licensed under a Creative Commons Attribution 4.0 International license.

Todo o conteúdo deste trabalho, exceto quando houver ressalva, é publicado sob a licença Creative Commons Atribição $\underline{4.0}$.

Todo el contenido de esta obra, excepto donde se indique lo contrario, está bajo licencia de la licencia Creative Commons Reconocimento 4.0. 


\section{PREFÁCIO}

\section{Paulo Freire, Vygotsky, Freinet, Dewey e Anísio Teixeira usariam o WhatsApp!}

Marco Silva

Costumo dizer: se estivessem vivos hoje e fossem incluídos ciberculturais, Paulo Freire, Vygotsky, Freinet, Dewey e Anísio Teixeira saberiam tomar a Web 2.0 ou a internet social e suas redes sociais como aliados capazes de materializar a açáo comunicacional da educaçáo autêntica, presencial e online, feita de conectividade, autoria, compartilhamento, colaboração, dialogia e interatividade.

Sim! Essas referências internacionais em educação realizaram suas docências e pesquisas acadêmicas no cenário midiático de que dispunham - imprensa, rádio e TV -, em que prevaleceu o paradigma unidirecional determinando a interaçáo emissor-receptor. Porém, em seus livros, concebem a pedagogia como prática potencializadora da autonomia, diversidade, interaçáo, dialógica e democracia em sala de aula. Essa percepçáo da educaçáo coexistiu desconfortável com o modus operandi das tecnologias de informação que eles conheceram, ainda que tenham lançado máo delas para divulgação de conteúdos e promover estratégias de aprendizagem como assistir a um filme, ler um texto e ouvir um áudio.

Se estivessem vivos e atentos ao cenário comunicacional da cibercultura ou da cultura digital, Freire, Vygotsky, Freinet, Dewey e Teixeira se sentiriam muito à vontade para fazer uso do smartphone, do tablet e do laptop como aliados em sala de aula. Saberiam

1 Sociólogo, doutor em Educação, professor da Faculdade de Educação da Universidade do Estado do Rio de Janeiro (UERJ) e autor do livro Sala de aula interativa.

E-mail: mparangole@gmail.com 
explorar suas telas não meramente como planos de transmissão para assistir a filme, ler texto e ouvir áudio, mas como ambientes de imersão, manipulação e interlocução, com janelas, ícones e aplicativos móveis abertos a múltiplas conexôes, que permitem intervençóes e modificações autorais e colaborativas nos conteúdos e na comunicação.

Se estivessem vivos e atentos ao nosso cenário midiático, perceberiam que o aprendiz migra da condição de espectador com um controle remoto nas máos para a de participador que opera naturalmente com a tela tátil, imersiva, em rede conversacional, que lhe permite adentramento, autoria, colaboração e o gesto instaurador que cria e alimenta sua experiência comunicacional.

Se fossem usuários das redes digitais, dos blogs, dos wikis, veriam que o tripé fundamental da comunicação passa por uma modificação radical favorável a suas concepções de educação, quando a mensagem muda de natureza, o emissor muda de papel e o receptor muda de status.

- $\mathrm{O}$ emissor não emite mais, no sentido que se entende habitualmente, uma mensagem fechada. Ele oferece um leque de elementos e possibilidades à manipulação do receptor.

- A mensagem não é mais "emitida", não é mais um mundo fechado, paralisado, imutável, intocável, sagrado. É um mundo aberto, modificável, na medida em que responde às solicitaçôes daquele que a consulta.

- O receptor não está mais em posição de recepção clássica. Ele é convidado à livre autoria colaborativa. A mensagem ganha sentido sob sua intervenção.

Se estivessem vivos e atentos ao espírito do nosso tempo, Freire, Vygotsky, Freinet, Dewey e Teixeira muito provavelmente adotariam o WhatsApp, que contempla a participação de sujeitos dialogantes na dinâmica da autoria e da cocriação da comunicação, da aprendizagem e da formação. Esse aplicativo favorece a docência e a aprendizagem em sala de aula presencial e online porque permi- 
te reunir interlocutores em bidirecionalidade, multidirecionalidade, comunicação síncrona e assíncrona, com troca de texto, áudio, imagem e vídeo, documentos em PDF e ligaçôes gratuitas por meio de conexão com a internet.

Por sua vez, a docência ciberincluída e inspirada no legado dos mestres citados saberia intuitivamente lançar máo do WhatsApp para promover a extensão da sala de aula presencial no ciberespaço e aí mobilizar a autêntica educação cidadá. Entretanto, ainda que intuitiva, a utilização desse aplicativo não deixaria de lançar mão das contribuiçôes reunidas na coletânea intitulada WhatsApp e educação: entre mensagens, imagens e sons, organizada por Cristiane Porto, Kaio Eduardo Oliveira e Alexandre Chagas. Esse volume reúne trabalhos de pesquisadores antenados com a cibercultura ou com a cultura digital e com a tradição crítica ou emancipatória da educação e trata de inúmeras funcionalidades, vantagens e possibilidades pedagógicas do WhatsApp. Os textos estão organizados em três segmentos: 1) What$s A p p$, mediação e processos comunicativos; 2) WhatsApp e processos educativos; e 3) WhatsApp, autoria e prática docente.

\section{WhatsApp, mediaçáo e processos comunicativos}

Dá início ao primeiro segmento desta coletânea o texto "Gestão em rede na primavera secundarista", das autoras Andrea Lapa e Gilka Girardello. Seu objeto é a análise de uma experiência pedagógica que articulou uma disciplina de pós-graduação em uma universidade federal e as ocupaçóes de escolas por estudantes em defesa da educação durante a chamada "Primavera Secundarista" de 2016. O trabalho baseia-se nos referenciais das teorias da comunicação, dos estudos culturais e da mídia-educação, bem como nos conceitos-eixo do programa Cultura Viva do Ministério da Cultura (MinC): autonomia, protagonismo, empoderamento e gestão em rede. Como o foco da disciplina eram as relaçôes entre educação, cultura digital e culturas populares no contexto brasileiro contemporâneo, a emergência das 
lutas estudantis levou a turma a constituir-se como um coletivo solidário que passou a apoiar diretamente os movimentos protagonizados pelos secundaristas. Um dos espaços comunicativos mais utilizados nessa experiência, tanto para comunicação interna quanto para comunicação externa, foi o aplicativo WhatsApp Messenger. Cada estudante fazia a ponte dos acontecimentos e contatos de sua própria rede dentro das escolas ocupadas com os outros estudantes e as professoras da turma. Para tal, foi criado o grupo EcoAçâo, que acolheu todas as trocas discursivas do grupo, em texto, áudio e vídeo, fonte preciosa de dados que permitiu analisar a experiência midiático-educativa da disciplina e essas novas formas de comunicação contemporâneas como espaços de formação da cultura digital. Na análise do processo, o texto identifica contribuiçóes para a reflexão no campo educacional, especialmente diante da persistência de uma distância entre a universidade e as escolas, e do risco de que a proposta de educar com, para e através das mídias possa às vezes reduzir-se à retórica. Em suma, o texto discute aspectos favoráveis à invenção pedagógica no campo da Educação e da Comunicação.

O segundo texto da primeira seção, de autoria de J. António Moreira e Sara Dias Trindade, tem como título "O WhatsApp como dispositivo pedagógico para a criação de ecossistemas educomunicativos". Reflete sobre a aplicabilidade pedagógica do Whats App procurando analisar possibilidades e potencialidades desse dispositivo na criação e desenvolvimento de ecossistemas digitais comunicativos em diferentes níveis de ensino. Seus autores estáo duplamente atentos: 1) para a potência do aplicativo capaz de proporcionar aos docentes e estudantes oportunidades de aprendizagem desenhadas “à medida” e passíveis de serem concretizadas em praticamente qualquer lugar e a qualquer hora; 2) ao mesmo tempo, para a mudança de paradigma educativo revelando cada vez mais tênue a linha que separa a educação formal da informal e não formal, bem como a necessidade de urgente 
otimização das potencialidades do denominado "software social". Com base nessa dupla atençáo, o texto trata de potencialidades do WhatsApp para o desenvolvimento de estratégias de aprendizagem motivadoras para a aquisição de competências pelos estudantes, cada vez mais imersos no mundo digital.

O último texto do primeiro segmento dedicado a mediaçáo e processos comunicativos tem como título "O uso do WhatsApp como prática sociointeracionista e espaço de aproximação entre surdos e ouvintes". Seus autores, Huber Kline Guedes Lobato, Rubens Alexandre de Oliveira Faro e Renata Moraes de Oliveira, partem das seguintes questóes: a) de que forma o aplicativo Whats $A p p$ contribui na interação entre surdos e ouvintes?; b) quais as percepçóes de participantes de um grupo do WhatsApp sobre a interação entre surdos e ouvintes?; c) quais as contribuiçôes do aplicativo para aproximar o mundo de surdos ao mundo de ouvintes? Com base nessas questóes específicas, eles dão conta do objetivo principal do texto, que é analisar a contribuição do WhatsApp para a interação entre surdos e ouvintes. Para dar conta desse desafio, trabalham com: a) preceitos sociointeracionistas segundo a perspectiva vygotskiana; b) percepçóes de participantes de um grupo do WhatsApp sobre a interação entre surdos e ouvintes; e c) análise das contribuiçóes do aplicativo WhatsApp para aproximar o mundo de surdos ao mundo de ouvintes. Os resultados do estudo apresentado no texto revelam que: a) o Whats $A p p$ contribui na interação entre surdos e ouvintes; b) os participantes partilham informaçóes e conhecimentos por meio do aplicativo; e c) o uso do Whats $A p p$ propicia, de forma equânime, condiçóes de interação entre surdos e ouvintes. Em suma, o texto revela que o uso do aplicativo, como prática sociointeracionista, é um espaço de aproximação entre surdos e ouvintes que contribui com o uso e difusão da Língua Brasileira de Sinais (Libras) e da Língua Portuguesa em sua modalidade escrita, seja por meio de chamadas de vídeos ou por mensagens de textos. 


\section{WhatsApp e processos educativos}

Dedicada a processos educativos, a segunda seção do livro tem como primeiro texto "Interaçôes no ciberespaço: estudos e pesquisas sobre o WhatsApp na educação no Brasil e em Portugal”. Seus autores, Ronaldo Nunes Linhares, Alexandre Meneses Chagas e Elbênia Marla Ramos Silva, mapeiam e analisam a produção científica sobre o uso do WhatsApp como plataforma de comunicação e educação no processo de aprendizagem. Para revelar o que está sendo feito e em que estágio se encontram os estudos e pesquisas sobre esse tema, optaram por: a) quantificar e mapear os dados sobre dissertaçóes e teses que tenham como objeto o WhatsApp/educação no Brasil e Portugal, de 2009 até 2017; b) identificar nessa produção as tendências teórico-metodológicas, autorias e resultados, procurando responder às seguintes questóes: quando, onde, quem, o quê, com que objetivo, como e quais os resultados; e c) comparar a produção dos dois países procurando estabelecer aproximaçóes e distanciamentos na busca de compreender a relevância e contribuição do WhatsApp no processo de aprendizagem. Atentos ao desafio de mapear essa produção ainda em construção, considerando a novidade e inovação do objeto no campo da educação, os autores têm consciência de que lidam com as marcas iniciais do WhatsApp no território da cibercultura e no campo da educação.

O texto de Cristiane de Magalhães Porto, Kaio Eduardo de Jesus Oliveira e André Luiz Alves, intitulado "Expansão e reconfiguraçôes das práticas de leitura e escrita por meio do WhatsApp", discute as reconfiguraçóes das habilidades e práticas de leitura e escrita no aplicativo WhatsApp Messenger. A partir de pesquisa bibliográfica, defende o argumento de que o aplicativo: a) tem favorecido processos comunicativos "mais interativos" por meio da troca de mensagens instantâneas; e b) tem possibilitado novas práticas de leitura e de escrita cotidianas, mediante a convergência de elementos próprios do aplicativo, do hipertexto e da cultura digital, tais como: emojis, emotions, imagens, áudios e vídeos, que passam 
a integrar as práticas de leitura e escrita, atualizando a concepção clássica de letramento.

Lúcia Amante e Lígia Fontana são autoras do texto "WhatsApp e a aprendizagem: realidade ou ilusão?". Considerando que a adoção de plataformas e ferramentas digitais pode contribuir significativamente para o desenvolvimento de habilidades e competências compatíveis com as novas demandas sociais que se colocam à aprendizagem no ensino superior, elas discutem no texto a utilizaçáo do WhatsApp como aplicativo que promove a aprendizagem colaborativa e ubíqua, permitindo aos estudantes construir um percurso próprio de aprendizagem. Ademais procuram identificar os tipos de funçóes que, no processo de aprendizagem, os estudantes atribuem a esse aplicativo, bem como entender as limitaçóes do WhatsApp, tendo por base uma experiência de utilização desenvolvida com um grupo de estudantes de educação em contexto universitário.

O texto "WhatsApp com função Stories: ensinar e aprender na magia do instante", de Edvaldo Souza Couto e Joana Dourado França de Souza, chama especial atenção para a função Stories, uma novidade incorporada ao aplicativo que permite o compartilhamento de fotos e vídeos por tempo determinado. A função Stories, já conhecida no SnapChat, outro aplicativo de rede social, surpreende porque difere de outras redes sociais em que as mensagens eram destinadas ao registro eterno. $\mathrm{Na}$ função Stories, cada publicação é condenada a desaparecer em pouco tempo. O texto chama a atenção para a promoção do esquecimento por meio de mensagens autodestrutivas e problematiza a adoção e recorrência dessa função em várias redes sociais. Alerta para a dissolução de características específicas da participação nas redes sociais e para o risco de padronização dos ambientes antes marcados por experiências ricas que ressaltavam a diversidade de mecanismos. A partir de estudos sobre a cibercultura e as redes sociais digitais no âmbito da educação, apresenta resultados de uma pesquisa qualitativa com um grupo de professores que relata possibilidades pedagógicas do 
WhatsApp com a função Stories. São discutidos os significados do ensinar a aprender, lembrar e esquecer, registrar e apagar conteúdos na magia do instante em nossas comunicaçóes ubíquas.

"WhatsApp: cenário para discussóes e reflexôes sobre a permissividade e limite da interação de crianças e adolescentes com o universo digital" é o texto assinado por Lynn Alves e Velda Torres. Seu foco é a reação dos pais à adesão da juventude aos artefatos sociotécnicos contemporâneos que vêm provocando mudanças na forma como as pessoas se organizam, acessam informaçóes e produzem conhecimentos, a exemplo dos telefones móveis que se converteram em computadores na palma da máo, possibilitando acesso a arquivos armazenados nas nuvens computacionais, gerenciamento de e-mails e processos comunicacionais. Alguns pais têm estabelecido limites para interação dos filhos com o universo digital, inclusive pais pesquisadores da cultura digital. $\mathrm{O}$ texto aborda as angústias desses pais em torno do seu papel diante do desejo de interação frequente dos filhos com as tecnologias digitais. As angústias foram registradas nas discussões em um grupo no Whats $A p p$ com membros do Centro de Pesquisa e Desenvolvimento Comunidades Virtuais - CV - Uneb. O texto analisa essas angústias e apresenta o WhatsApp como espaço para reflexão e formação de professores e pesquisadores.

O texto "Conversas ubíquas via Whatsapp: ambiências formativas multirreferenciais", de Rosemary Santos, Felipe Carvalho e Tânia Lúcia Magdalena, resulta de pesquisa que investigou a aproximação do currículo universitário das práticas cotidianas da cibercultura, arquitetando e planejando ambiências formativas emergentes de práticas colaborativas, autorais e abertas. $\mathrm{O}$ estudo desenvolveu-se com os cotidianos de cursistas e um docente-pesquisador na disciplina Informática na Educação, do curso de licenciatura em Pedagogia, Uerj/Cederj/UAB, oferecida em 12 polos localizados em municípios do Estado do Rio de Janeiro em 2014. As conversas do WhatsApp tomadas como dispositivos de pesquisa revelaram possibilidades de 
maior interação entre subjetividades próprias dos praticantes pesquisados. Com base nessa investigação, o texto aborda as práticas que acontecem cotidianamente com os usos dos dispositivos móveis, nos deslocamentos de espaços e tempos, em que as pessoas têm dinamizado a produção de enunciados sobre lugares e acontecimentos, expressando diferentes perspectivas sobre o mundo.

\section{WhatsApp, autoria e prática docente}

O texto de Carloney Alves de Oliveira "Entre processos formativos e interativos: o WhatsApp como espaço significativo na orientação e formação " abre o último segmento deste livro. Ele registra os resultados de pesquisa que investigou as contribuiçóes e as potencialidades do WhatsApp nos processos de orientação e formação de bolsistas do Programa Institucional de Bolsas de Iniciação Científica (Pibic) na Universidade Federal de Alagoas (UFAL). E reflete sobre a formaçáo do pedagogo em face do WhatsApp e atento às interaçóes entre os sujeitos envolvidos através de estratégias didáticas. Revela também o desejo por uma melhor prática na utilização do WhatsApp constatado no seu universo de pesquisa, formado por dois orientandos do Pibic, alunos do Curso de Licenciatura em Pedagogia da Ufal, à disposição para um acompanhamento sistemático e uma formação adequada, com apoio, diálogo e colaboração. Atesta também que o WhatsApp permite a configuração de novas maneiras de aprender e orientar pela interação e exploração do aplicativo - na experimentação e na colaboração -, inserindo os sujeitos e proporcionando espaços para reflexóes sobre o processo formativo na cultura digital.

"Diário online no WhatsApp: app-learning em contexto de pesquisa-formação na cibercultura" é o texto de Alexsandra Barbosa, Edméa Santos e Mayra Ribeiro. Parte do entendimento de que a cultura contemporânea tem proporcionado diferentes usos das tecnologias móveis no âmbito da educação, tais como a utilização de celulares, smartphones e tablets na pesquisa e na formação 
de professores. E confirma que os aplicativos ensejam situações de aprendizagem nas quais os sujeitos interagem e aprendem em mobilidade e ubiquidade, possibilitando, assim, novos modos de produção de saberes. Ao articular tecnologias e aplicativos com a "pesquisa-formação na cibercultura", as autoras do texto revelam sua abordagem sobre o app-learning, modo como denominamos "saberesfazeres" provenientes do uso de aplicativos nos processos de "aprendizagemensino". O texto revela que os aplicativos podem ser utilizados nas pesquisas como dispositivos que registram, através da escrita, da fotografia, de áudios e de vídeos, o que é vivenciado. Ao mesmo tempo, reflete sobre o uso do WhatsApp Messenger como diário online no processo formativo de uma pesquisa-formação na cibercultura no contexto do Grupo de Pesquisa, Docência e Cibercultura (GPDOC).

O texto "A web 2.0 e os software sociais: outros espaços tempos multirreferencias na iniciação à docência" nasceu do esforço de compreender e explorar as potencialidades dos recursos presentes nas tecnologias móveis utilizadas no Programa Institucional de Bolsa de Iniciação à Docência (Pibid) da Universidade Federal de Sergipe, com os bolsistas de iniciação à docência e com supervisoras das escolas vinculadas ao Pibid/Pedagogia. Os autores, Simone Lucena, Arlene Araújo Domingues Oliveira e Gilson Pereira dos Santos Junior, realizaram a pesquisa durante a formação no Pibid utilizando o WhatsApp Messenger. Como resultado, observaram que os grupos criados com os sujeitos da pesquisa passaram a utilizar esse aplicativo como outro espaçotempo de formação. De acordo com os autores, o aplicativo permite a criação de um espaço multirreferencial com possibilidades de socializar, interagir e narrar instantaneamente todas as açóes desenvolvidas nos diferentes ambientes de aprendizagem. Simone, Arlene e Gilson sugerem ainda que os softwares sociais potencializam a criatividade e a colaboração entre seus usuários, favorecem a divulgação de suas autorias em forma de texto, áudio, imagem e vídeo. 
Para finalizar o texto de Rosemary Lacerda Ramos "Ciência com leveza: o WhatsApp como artefato pedagógico na disciplina metodologia do trabalho científico". O texto resulta de investigação sobre as potencialidades didáticas do WhatsApp como artefato de comunicação e mediação didático-pedagógica no percurso da disciplina Metodologia Científica. O WhatsApp foi escolhido por ser um dos mais populares aplicativos de mensagem multiplataforma com relevante potencial comunicacional. Por sua vez, a delimitação da disciplina Metodologia Científica como locus da experiência se justifica por ser fundamental no desenvolvimento de produçóes científicas dos estudantes que ingressam no ensino superior e ao longo do curso são estimulados a desenvolver trabalhos científicos como parte dos requisitos de avaliação, além de contribuir com o letramento acadêmico e iniciação à prática de pesquisa com suas diversas circunstâncias de natureza técnica e estética. A "pesquisa-ação” realizada com seis turmas de pós-graduação adotou o WhatsApp como artefato mediador do processo ensino-aprendizagem na referida disciplina. Os resultados revelaram uma grande aceitação, maior interação entre os pares, engajamento e motivaçáo para o estudo, contribuição com a construção coletiva do conhecimento, participação e colaboração dos discentes no processo de ensino e aprendizagem para além dos limites físicos da sala de aula com intensificação da sua participação nas atividades didáticas.

Em 2017, ano de publicação desta coletânea, o WhatsApp completa oito anos como software de autoria, compartilhamento, conectividade e colaboração mais popular no Brasil. Se ainda estivessem entre nós e pudessem ler os textos aqui reunidos, Freire, Vygotsky, Freinet, Dewey e Teixeira concordariam que o cenário sociotécnico da internet social está em sintonia paradigmática com o que os reúne em favor da educação cidadá: autonomia, diversidade, interação, dialógica e democracia. Temos a confluência de uma tradição pedagógica transtemporal 
forjada no cenário analógico desfavorável e a atualidade digital pujante com forte adesão social. Essa confluência é histórica e nos faz ver que temos uma situação de vantagem quando estão disponíveis as condiçôes de fazer algo em favor da formação de professores e da educação em nosso tempo. 